\title{
Effect of calcium-enriched high-fat diet on calcium, magnesium and zinc retention in mice
}

\author{
Lucía Pérez-Gallardo $^{1 *}$, Marta Gómez ${ }^{1}$, Pilar Parra ${ }^{2}$, Juana Sánchez ${ }^{2}$, Andreu Palou ${ }^{2}$ and Francisca Serra ${ }^{2}$ \\ ${ }^{1}$ Department of Biochemistry, Molecular Biology and Physiology, University of Valladolid, Campus de Soria, Soria 42004, Spain \\ ${ }^{2}$ Laboratory of Molecular Biology, Nutrition and Biotechnology, CIBER de Fisiopatología de la Obesidad y Nutrición \\ (CIBEROBN), University of the Balearic Islands, Cra. de Valldemossa km 7.5, Palma de Mallorca 07122, Spain
}

(Received 6 May 2008 - Revised 14 August 2008 - Accepted 2 September 2008 - First published online 6 November 2008)

The aim of this work was to assess the effects of a high-fat diet enriched in $\mathrm{Ca}$, which accompanies lower body fat deposition, on mineral depots, as well as to assess the potential role of adaptive thermogenesis in mice. Male mice were fed ad libitum a high-fat (43\%) diet with a Ca content of $4 \mathrm{~g} / \mathrm{kg}$ from calcium carbonate (control group) or $12 \mathrm{~g} / \mathrm{kg}$ (42\% from milk powder and the rest from calcium carbonate) (Ca group) for $56 \mathrm{~d}$. Body weight, food intake and urine were periodically collected. Tissue samples were collected when the mice were killed and the composition was determined. Expression of uncoupling proteins was determined by Western blotting. Mineral content was measured by flame atomic absorption spectrometry. Lower body weight gain and fat accretion was found in the Ca group. This could not be attributable to lower gross energy intake or to activation of adaptive thermogenesis. Although significant urine mineral loss was found in the $\mathrm{Ca}$ group, preservation of mineral depots in bone was observed. Our data support the fact that adding more Ca to the diet, using a combination of calcium carbonate plus milk powder containing among other things higher $\mathrm{Zn}$ and $\mathrm{Mg}$, contributes to counteracting obesity and improving lipid metabolism.

Dietary calcium: Zinc: Magnesium: Obesity

Observational and epidemiological data have shown that a low-Ca diet may be a risk factor for obesity development, and beneficial aspects of milk components on metabolic syndrome are gaining strength ${ }^{(1,2)}$, even though intervention trials have yielded inconsistent results to date ${ }^{(3)}$.

The molecular mechanisms responsible for the impact of dairy products on body weight and fat have been studied in animal models with important contributions from the group of $\mathrm{Zemel}^{(4)}$. Using a transgenic animal model (over-expressing agouti protein under the control of the aP2 promoter), Zemel and co-workers showed that dietary $\mathrm{Ca}$ could influence fat deposition by direct modulation on adipocyte metabolism, increasing thermogenesis and lipolysis and decreasing lipogenesis following a high-Ca $\operatorname{diet}^{(5,6)}$. However, in normal mice, activation of thermogenesis does not seem to be responsible for the lower rate of weight gain seen with a high-fat diet enriched with dairy $\mathrm{Ca}^{(7)}$.

Minerals have been suggested to beneficially modulate cardiovascular risk factors ${ }^{(8,9)}$. However, there are few data available concerning dietary mineral interactions. The aim of the present work was to assess the effects of a high-fat diet enriched in $\mathrm{Ca}$ on body fat and mineral bone retention, particularly on $\mathrm{Ca}, \mathrm{Mg}$ and $\mathrm{Zn}$, as well as to assess the potential involvement of adaptive thermogenic mechanisms in mice.

\section{Experimental methods}

Animals and diets

Twelve male mice (C57BL/6J) (Charles River, Spain) weighing approximately $21 \mathrm{~g}$ were housed in groups of three and kept in a single metabolic cage throughout the experiment under controlled conditions. After a 1-week adaptation, mice received ad libitum either a control diet or a high-Ca diet (Research Diets Inc., New Brunswick, NJ, USA) for $56 \mathrm{~d}$. Both diets provided the same digestible energy content $(19 \mathrm{~kJ} / \mathrm{g}), 20 \% \mathrm{~kJ}$ as protein (casein) and $43 \% \mathrm{~kJ}$ as fat (lard and soyabean oil). In addition, the high-Ca diet supplied $1.2 \%(\mathrm{w} / \mathrm{w})$ in $\mathrm{Ca}$ (from calcium carbonate and milk powder), three times higher than control group $(0.4 \%$ w/w, exclusively from calcium carbonate). High-Ca diet was aimed to supply $42 \%$ Ca from non-fat dry milk which also provided higher levels of $\mathrm{Mg}(1.09 \mathrm{~g} / \mathrm{kg})$ and $\mathrm{Zn}(0.05 \mathrm{~g} / \mathrm{kg})$ than the control diet $(\mathrm{Mg}, 0.57 \mathrm{~g} / \mathrm{kg} ; \mathrm{Zn}$, $0.03 \mathrm{~g} / \mathrm{kg}$ ). Food and water intake and body weight were recorded weekly.

Abbreviations: BAT, brown adipose tissue; UCP, uncoupling protein.

* Corresponding author: Dr Lucía Pérez-Gallardo, fax + 34975 129401, email llpegall@bio.uva.es 
All experimental procedures were performed according to the national and institutional guidelines for animal care and use at the university.

\section{Sampling}

Urine was collected twice a week from each cage, and measured and stored at $-20^{\circ} \mathrm{C}$ for posterior analysis. Animals were killed by decapitation at the end of the experiment; tissues were dissected, weighed, rinsed with saline containing $0.1 \%$ diethyl pyrocarbonate (Sigma, Madrid, Spain), frozen with nitrogen liquid and stored at $-70^{\circ} \mathrm{C}$ until analysis.

\section{Analytical procedures}

Ashed femur samples and aliquots of urine were measured after appropriate dilution by flame atomic absorption spectrometry (Perkin-Elmer 272). Liver glycogen was extracted ${ }^{(10)}$ and the released glucose was determined by enzymatic assay $^{(11)}$. Lipids were extracted ${ }^{(12)}$ and TAG and cholesterol content were determined using commercial kits from Biotécnica 2000. Liver protein content was determined from homogenised samples in PBS ${ }^{(13)}$.

Muscle and brown adipose tissue (BAT) proteins were extracted using Tripure reagent (Roche, Barcelona, Spain). Protein concentration was determined by the bicinchoninic acid assay (Pierce) using a bovine serum albumin standard. Uncoupling protein 1 (UCP-1) in BAT and UCP-3 in muscle were determined by Western blotting ${ }^{(7)}$. $\beta$-Actin was determined in representative gels to confirm equal protein load charge between samples. The immunocomplexes were revealed using an enhanced chemiluminescence detection system (ECL ${ }^{\mathrm{TM}}$; Amersham Biosciences, Barcelona, Spain) and visualised by exposure to sensitive films (Hyperfilm $^{\mathrm{TM}}$ ECL; Amersham Biosciences). The films were scanned in a ChemiGenius (SynGene) using the software GeneSnap version 6.03 , and the bands were quantified using GeneTools version 3.04 (SynGene).

\section{Statistical analysis}

The effect of $\mathrm{Ca}$ treatment on body weight was assessed by ANOVA followed by post hoc analysis. Comparison between control and $\mathrm{Ca}$ animals for the rest of the variables was assessed by Student's $t$ test. The analysis was performed using the SPSS program for Windows version 14 (SPSS, Chicago, IL, USA). Urine mineral data from control and $\mathrm{Ca}$ animals were analysed on each day of treatment; no differences were observed throughout the period, and therefore data are presented as the average of all samples collected. The level of significance was set at $P<0.05$. Data are presented as means with their standard errors.

\section{Results}

Food consumption did not differ between groups during the period studied 52.3 (SEM 1.7) $\mathrm{kJ} / \mathrm{d}$ in the control group and 53.1 (SEM 2.1) $\mathrm{kJ} / \mathrm{d}$ in the $\mathrm{Ca}$ group. The amount of food eaten implies an intake of 10.8 (SEM 0.3$) \mathrm{mg} \mathrm{Ca} / \mathrm{d}, 1.5$ (SEM 0.04) $\mathrm{mg} \mathrm{Mg} / \mathrm{d}$ and 0.08 (SEM 0.002) $\mathrm{mg} \mathrm{Zn} / \mathrm{d}$ in the control group and $46.8(\mathrm{SEM} 1.2) \mathrm{mg} \mathrm{Ca} / \mathrm{d}, 4 \cdot 2$ (SEM 0.1) $\mathrm{mg}$
$\mathrm{Mg} / \mathrm{d}$ and 0.2 (SEM 0.05) $\mathrm{mg} \mathrm{Zn} / \mathrm{d}$ in the $\mathrm{Ca}$ group. No difference in water consumption was seen between groups 4.27 (SEM 0.08) $\mathrm{ml} / \mathrm{d}$ in controls and 4.42 (SEM 0.05) $\mathrm{ml} / \mathrm{d}$ in the $\mathrm{Ca}$ group.

Body weights were significantly different between groups from week 6 onwards $(P=0.017)$ and, by the end of the study, Ca-fed animals weighed less than control mice (Fig. 1). During the treatment, the control group gained 7.61 (SEM 0.7) g, whereas animals fed the high-Ca diet gained 4.41 (SEM 0.2) g $(P=0.003)$.

Adipose tissue weights were significantly smaller in mice fed the high-Ca diet than in controls, mesenteric was the least affected $(50 \%)$ and the retroperitoneal the highest (69\%) compared with controls. BAT was also $40 \%$ lower in the $\mathrm{Ca}$ group than in the control group (Table 1). Saturated lipid concentration and TAG were determined in epididymal adipose tissue and were not different between the control and $\mathrm{Ca}$ group (data not shown).

Liver weight was not affected by dietary treatment and the same was seen for glycogen, proteins, saturated lipid and cholesterol concentrations in liver. However, TAG levels were reduced by half in the $\mathrm{Ca}$ group.

UCP-1 levels in BAT were not different between control and Ca-fed animals (100 (SEM 11.2) \% in control group; 110 (SEM 15.4) \% in Ca group). The same pattern was seen in muscle UCP-3 levels (100 (SEM 10.5) \% in control; 89.1 (SEM 11.7) \% in Ca group).

No significant differences were observed with respect to the volume of urine eliminated daily (control 0.77 (SEM 0.05) v. Ca $0 \cdot 89$ (SEM 0.07) $\mathrm{ml} / \mathrm{d}, P=0 \cdot 19)$. However, Ca (control $5 \cdot 18$ (SEM 1.0) v. Ca 603 (SEM 79) $\mu \mathrm{g} / \mathrm{d}, P=2.3 \times 10^{-6}$ ), Mg (control 0.50 (SEM 0.1) v. Ca 494 (SEM 70) $\mu \mathrm{g} / \mathrm{d}, P=5 \cdot 3 \times 10^{-6}$ ) and $\mathrm{Zn}$ (control $21.5\left(\right.$ SEM 1.7) v. Ca 89.2 (SEM 6.0) $\mu \mathrm{g} / \mathrm{d}, P=3.6 \times 10^{-8}$ ) urine excretion were significantly higher in the Ca group than in controls. To assess mineral deposition, femur composition was analysed and no statistically significant effects either on femur weight or on $\mathrm{Ca}, \mathrm{Mg}$ or $\mathrm{Zn}$ content at the end of treatment were found (data not shown).

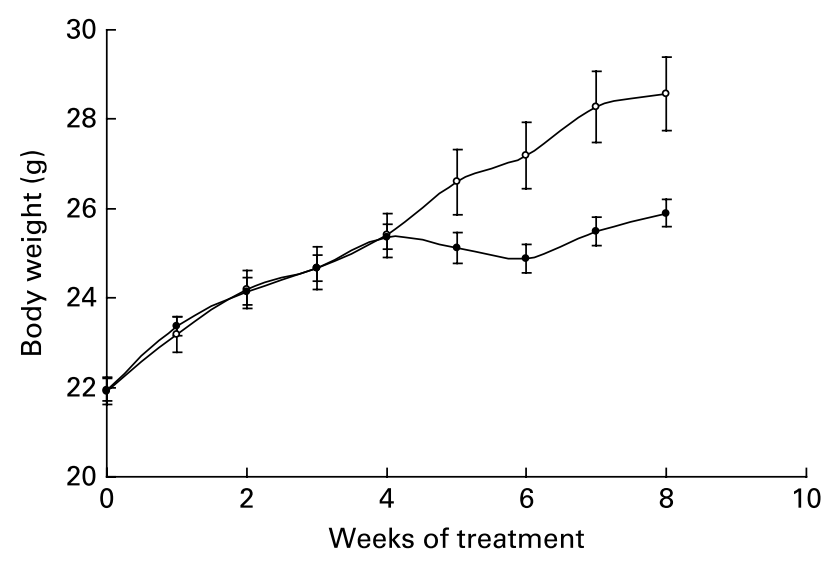

Fig. 1. Body weight evolution of animals fed either the control $(\bigcirc)$ or the high-calcium ( $)$ diet for $56 \mathrm{~d}$. Values are means with their standard errors depicted by vertical bars (six animals for each group). Body weights were significantly different from week 6 onwards $(P=0.017)$, determined by repeated-measures ANOVA. 
Table 1. Fat depot weights and liver weight and composition in mice fed either the control or the high-calcium diet for $56 \mathrm{~d}^{*}$

(Mean values with their standard errors)

\begin{tabular}{|c|c|c|c|c|c|}
\hline & \multicolumn{2}{|c|}{$\begin{array}{l}\text { Control diet } \\
\quad(n 6)\end{array}$} & \multicolumn{2}{|c|}{$\begin{array}{l}\text { Calcium diet } \\
(n 6)\end{array}$} & \multirow[b]{2}{*}{$P \dagger$} \\
\hline & Mean & SEM & Mean & SEM & \\
\hline \multicolumn{6}{|l|}{ Adipose tissue weight (mg) } \\
\hline Epididymal & 826 & 130 & 381 & $9 \cdot 7$ & 0.009 \\
\hline Inguinal & 533 & 55 & 222 & $9 \cdot 3$ & 0.002 \\
\hline Mesenteric & 302 & 42 & 151 & 15 & 0.015 \\
\hline Retroperitoneal & 267 & 33 & 81 & $6 \cdot 9$ & 0.002 \\
\hline Interscapular brown fat & 85 & $6 \cdot 5$ & 51 & $2 \cdot 4$ & 0.001 \\
\hline Liver weight (g) & 1.15 & 0.07 & $1 \cdot 18$ & 0.02 & 0.66 \\
\hline Glycogen $(\mathrm{mg} / \mathrm{q})$ & $20 \cdot 3$ & 1.3 & 18.0 & 1.9 & 0.33 \\
\hline Protein $(\mathrm{mg} / \mathrm{g})$ & $49 \cdot 0$ & $4 \cdot 1$ & 49.5 & 3.9 & 0.93 \\
\hline Saturated lipids (mg/g) & $6 \cdot 36$ & 0.5 & $6 \cdot 20$ & 0.5 & 0.85 \\
\hline Cholesterol $(\mu \mathrm{g} / \mathrm{g})$ & 175 & 12 & 180 & 15 & 0.77 \\
\hline TAG $(\mu \mathrm{g} / \mathrm{g})$ & 995 & 11 & 473 & 91 & 0.005 \\
\hline
\end{tabular}

${ }^{*}$ For details of procedures and diets, see Experimental methods.

† Statistically significant differences between groups were determined by Student's $t$ test.

\section{Discussion}

The aim of the present work was to assess the effects of highfat diet enriched in $\mathrm{Ca}$, which has been previously associated with a lower body fat deposition, on $\mathrm{Ca}, \mathrm{Mg}$ and $\mathrm{Zn}$ bone retention, as well as on thermogenic capacity in normal mice.

In accordance with previous results ${ }^{(7)}$, a reduction in body weight gain (by $12.7 \%$ ) was observed following the treatment with a high-Ca diet, which was also accompanied by lower fat deposition affecting all the adipose depots. In addition, hepatic lipid profile was not altered in the Ca group and the lower TAG content, associated with diminished hepatic lipogenesis, was in accordance with the lower fat accretion seen in adipose tissues.

No differences in food intake and in the expression of UCP-1 in BAT or in muscle UCP-3 were found, indicating that lower fat accretion in high-Ca-fed animals was not accompanied by lower energy intake either by activation of BAT or muscle thermogenesis, in accordance with results previously found in normal animals ${ }^{(7,14)}$ but not in a largely characterised transgenic model ${ }^{(15)}$.

Urine mineral excretion ( $\mathrm{Ca}, \mathrm{Mg}$ and $\mathrm{Zn}$ ) was increased in the $\mathrm{Ca}$ group and, to a certain extent, this could contribute to compromised mineral bioavailability. For example, high $\mathrm{Ca}$ to $\mathrm{Mg}$ dietary ratio has been proposed to pose a risk for $\mathrm{Mg}$ deficiency ${ }^{(16)}$ although, in practice, high-Ca diets have not been demonstrated to affect $\mathrm{Mg}$ retention in the long term $^{(17)}$. Furthermore, Ca, especially in the presence of phytate, may have an inhibitory effect on $\mathrm{Zn}$ absorption ${ }^{(18)}$ and a reduction in tibia $\mathrm{Zn}$ content has been reported in rats fed on high-Ca $\operatorname{diet}^{(19)}$, interestingly this does not seem to happen in the present experimental conditions. The preservation of $\mathrm{Ca}, \mathrm{Mg}$ and $\mathrm{Zn}$ content in femur, despite the higher urine excretion, supports the fact that body levels of these minerals are not compromised in the $\mathrm{Ca}$ group, at least during the period studied.

In conclusion, the present results support a lower body weight gain and lower body fat accretion in adult mice fed a high-fat diet enriched with dairy $\mathrm{Ca}$ with respect to those fed with standard Ca levels. This could not be attributable to a lower gross energy intake or to activation of thermogenesis in BAT or muscle. Although significant urine mineral loss was found in Ca-fed animals, the presence of dairy $\mathrm{Ca}$ was accompanied by preservation of mineral depots in bone. Further characterisation of cellular metabolism of these minerals would be necessary to attain total comprehension of their role in diminishing fat accretion. Nevertheless, the present data support the fact that adding more $\mathrm{Ca}$ to the diet, using a combination of milk powder containing among other things higher $\mathrm{Zn}$ and $\mathrm{Mg}$, contributes to counteract obesity and improves lipid metabolism in high-fat-fed mice.

\section{Acknowledgements}

This work was supported by grants from the Spanish Government (AGL2004-07 496 and AGL2006-04 887) and European Commission (European Nutrigenomics Organisation, NUGOFP6-506360). CIBER de 'Fisiopatología de la Obesidad y Nutrición' is an initiative of ISCIII. P. P. is a recipient of a fellowship from the Spanish Government. M. G. took care of animal handling, sample collections and analytical determinations. J. S. contributed to animal dissection and tissue sample collection. P. P. performed protein extraction and Western determinations. A. P., F. S. and L. P.-G. equally contributed to the conception and design of the study, interpretation of data and drafting of the manuscript. The authors declare no conflict of interest.

\section{References}

1. Barba G \& Russo P (2006) Dairy foods, dietary calcium and obesity: a short review of the evidence. Nutr Metab Cardiovasc Dis 16, 445-451.

2. Pfeuffer M \& Schrezenmeir J (2007) Milk and the metabolic syndrome. Obes Rev 8, 109-118.

3. Major GC, Chaput JP \& Ledoux M, et al. (2008) Recent developments in calcium-related obesity research. Obes $\operatorname{Rev} \mathbf{9}$, 428-445.

4. Zemel MB (2005) Calcium and dairy modulation of obesity risk. Obes Res 13, 192-193.

5. Zemel MB, Shi H, Greer B, et al. (2000) Regulation of adiposity by dietary calcium. FASEB J 14, 1132-1138.

6. Xue B, Greenberg AG, Kraemer FB, et al. (2001) Mechanism of intracellular calcium $\left(\left[\mathrm{Ca}^{2+}\right]_{\mathrm{i}}\right)$ inhibition of lipolysis in human adipocytes. FASEB J 15, 2527-2529.

7. Parra P, Bruni G, Palou A, et al. (2008) Dietary calcium attenuation of body fat gain during high-fat feeding in mice. $J$ Nutr Biochem 19, 109-117.

8. Scholz-Ahrens KE \& Schrezenmeir J (2000) Effects of bioactive substances in milk on mineral and trace element metabolism with special reference to casein phosphopeptides. $\mathrm{Br} J$ Nutr 884, Suppl. 1, S147-S153.

9. Vaskonen T (2003) Dietary minerals and modification of cardiovascular risk factors. J Nutr Biochem 14, 492-506.

10. Carroll NV, Longley RW \& Roe JH (1956) The determination of glycogen in liver and muscle by use of anthrone reagent. J Biol Chem 220, 583-593.

11. Trinder P (1969) Determination of blood glucose using an oxidase-peroxidase system with a non-carcinogenic chromogen. $J$ Clin Pathol 22, 158-161.

12. Folch J, Lees M \& Sloane Stanley GH (1957) A simple method for the isolation and purification of total lipids from animal tissues. J Biol Chem 226, 497-509. 
13. Bradford MM (1976) A rapid and sensitive method for the quantitation of microgram quantities of protein utilizing the principle of protein-dye binding. Anal Biochem 72, 248-254.

14. Papakonstantinou E, Flatt WP, Huth PJ, et al. (2003) High dietary calcium reduces body fat content, digestibility of fat, and serum vitamin D in rats. Obes Res 11, 387-394.

15. Sun X \& Zemel MB (2003) Effects of mitochondrial uncoupling on adipocyte intracellular $\mathrm{Ca}^{2+}$ and lipid metabolism. J Nutr Biochem 14, 219-226.
16. Seelig MS (1994) Consequences of magnesium deficiency on the enhancement of stress reactions; preventive and therapeutic implications (a review). J Am Coll Nutr 13, 429-446.

17. Whiting SJ \& Wood RJ (1997) Adverse effects of high-calcium diets in humans. Nutr Rev 55, 1-9.

18. Lonnerdal B (2000) Dietary factors influencing zinc absorption. J Nutr 130, 1378S-1383S

19. Forbes RM (1960) Nutritional interactions of zinc and calcium. Fed Proc 19, 643-647. 